\title{
Evaluation of the content and bioaccessibility of selected metals from barley grass
}

\author{
Sylwia Parzych ${ }^{1} \cdot$ Piotr Kwiatkowski $^{1}$ - Monika Asztemborska ${ }^{2} \cdot$ Lena Ruzik $^{1}$
}

Received: 29 January 2020 / Revised: 16 March 2020 / Accepted: 21 March 2020 / Published online: 31 March 2020

(c) The Author(s) 2020

\begin{abstract}
The evaluation of the content of zinc and copper in plant tissues of barley grass growing on enriched in zinc/copper solutions (sulphate, glycine complex, rutin complex) were studied by inductively coupled plasma mass spectrometry. The highest concentrations of $\mathrm{Zn}$ were found in the roots and leaves, growing on solutions enriched in the rutin-zinc(II) and sulphate solutions. The highest concentrations of $\mathrm{Cu}$ were found in the leaves, growing on solutions enriched in the glycine-copper(II) complex solutions. The research showed that the barley accumulates the zinc/copper from the nutrient solution, therefore, in the next step of the investigation the evaluation of bioaccessibility was carried out. The bioaccessibility of copper and zinc were evaluated from the various enriched cultivation solutions by the inductively coupled mass spectrometry coupled with size exclusion chromatography. Plants growing on solutions enriched in the zinc/copper complexes with amino acids (glycine) and flavonoids (rutin) accumulated excessive amounts of these elements in tissues. Additionally, the bioaccessibility is significantly higher than from the plant's tissues growing on zinc/copper salts solutions.
\end{abstract}

Keywords Bioaccessibility $\cdot$ Copper $\cdot$ Zinc $\cdot$ Barley grass $\cdot$ ICP-MS

\section{Introduction}

Nowadays, more and more consumers are choosing to introduce natural foods into their diets (plants, fruits, and vegetables). Because of the increase in popularity, an investigation is directed to determine the chemical forms of nutrients in it, especially metals. Additionally, due to the positive influence of metals present in food in the human body, the need to look for metal forms that are best bioaccessible also increases. Previous studies show that zinc and copper are better absorbed by the human body when are complexed with proteins, peptides or flavonoids [1-3].

One of the dietary supplements-barley grass-has gained significant popularity in recent years, because of the rich source of essential elements, including zinc, copper, manganese, and chromium [4]. Barley is widely consumed,

Lena Ruzik

lenka@ch.pw.edu.pl

1 Chair of Analytical Chemistry, Faculty of Chemistry, Warsaw University of Technology, Noakowskiego 3, 00-664 Warsaw, Poland

2 Isotopic Laboratory, Faculty of Biology, University of Warsaw, Warsaw, Poland because of its dietary and technological properties-production of beer [5] and functional foods [6, 7]. Moreover, several classes of compounds are present in barley which have a phenolic structure-responsible for antioxidant properties $[8,9]$ and are rich in micro- and macro elements, proteins and vitamins [4]. Barley grass has young green leaves and stems of vegetative growth stage from a seedling at 10 days after sprouting (barley sprout) to elongation stage (barley green) for a nutritional peak before the start of the reproductive cycle of barley [10]. Barley grass is not only consumed as a popular green-colored drink [11, 12], but also used in preventive chronic diseases, especially circulatory disorders, anticancer, reducing obesity, anti-diabetes, anti-arthritis, reducing cholesterol, antioxidant, and anti-inflammation $[12,13]$.

The determination of the content of elements in the food is important but not enough. However, it is necessary to specify the forms of elements, because this is the reason why some elements are better accessibility for the human organism than others [2,14]. So this is the reason, why it is important to check the different growth media of the planta solution with metal complexes and metal ions $[15,16]$. What is also important the examination of the accumulation of elements by plants and identification of the forms 
of metal which are responsible for better bioavailability for human organisms.

Due to that determination of the total concentration of metals in food does not provide information about their bioavailability in the human organism [6] and knowledge about the content of an element in the bioaccessible fraction is necessary to evaluate bioavailability [17], we need to find the tool which helps us to get the information on the bioaccessibility of important nutrients in food and food supplements. For that reason, this research aimed to: (1) evaluate the concentrations of copper and zinc in plant tissues of barley grass growing on enriched solutions and (2) evaluate the bioaccessibility of copper and zinc from the barley grass using the in vitro simulation of gastrointestinal digestion (two-step model with pepsin as a gastric juice and pancreatin as an intestinal juice). To the best of our knowledge, this is the first attempt to carry out bioaccessibility evaluation of metals in barley grass by the ICP-MS technique.

\section{Materials and methods}

\section{Reagents and chemicals}

Sodium chloride, ammonium acetate, rutin, glycine, nitric acids, hydrogen peroxide, zinc acetate, zinc sulfate, copper sulfate, and hydrochloric acid were purchased from Sigma Aldrich with analytical reagent grade. Pepsin from porcine gastric mucosa and pancreatin was of biological grade (Sigma-Aldrich, Buchs, Switzerland). Deionized water $(18 \mathrm{M} \Omega \mathrm{cm}$ ) prepared with a Milli-Q system (Millipore Elix 3, Millipore, Saint-Quentin, France) was used throughout. The SEC column was calibrated using the size exclusion standard (BIO-RAD, Warsaw, Poland).

\section{Instrumentation}

The determination of the concentration of elements in plant tissues (after mineralization and enzymatic extraction) was carried out by Agilent 7500a ICP MS as an element-specific detector. Ni-skimmer was installed in the interface, the position of a torch and nebulizer gas flow was adjusted daily with special emphasis to decrease the level of $\mathrm{CeO} / \mathrm{Ce}$ below $0.2 \%$ to minimize the risk of polyatomic interferences caused by oxides. The working conditions were optimized daily using a $10 \mu \mathrm{g} \mathrm{L}^{-1}$ solution of ${ }^{7} \mathrm{Li}^{+},{ }^{89} \mathrm{Y}^{+}$, and ${ }^{209} \mathrm{Bi}^{+}$in $2 \%(\mathrm{v} / \mathrm{v}) \mathrm{HNO}_{3}$. It was expected to obtain the highest signals for bismuth and yttrium and the lowest amount of oxide, polyatomic and doubly charged ions.

The screening for the metal complexes was carried out through size exclusion chromatography coupled to ICPMS. Prepared samples were analyzed on a Superdex 200 10/300GL (GE Healthcare Life Sciences) exclusion column with a bed volume of $24 \mathrm{~mL}$. Before the analysis, the column was calibrated with a mixture of thyroglobulin $(670 \mathrm{kDa}), \gamma$-globulin $(158 \mathrm{kDa})$, ovalbumin (44 kDa), myoglobin $(17 \mathrm{kDa})$, vitamin $\mathrm{B}_{12}(1.35 \mathrm{kDa})$. Chromatographic separations were performed using Agilent 1100 gradient HPLC pump (Agilent Technologies, Waldbronn, Germany) as the sample delivery system. Agilent 7500a ICP MS (Tokyo, Japan) was used as an on-line HPLC detector. All connections were made with PEEK tubing $(0.17 \mathrm{~mm}$ i.d.). Operational parameters are summarized in Table 1.

For the extraction procedures, Bandelin Sonorex Model 1210 ultrasonic bath (Bandelin, Berlin, Germany) and ultrafiltration were carried out using an MPW-350R centrifuge (MPW, Poland). Spectrophotometer UV-VIS (Merck, Germany).

\section{Plant cultivation}

Plant cultivation sets of 50 seeds of barley grass were germinated for 7 days in distilled water and transferred to $350 \mathrm{~mL}$ containers with water (control) or various zinc/ copper solutions (sulphate, glycine complex, rutin complex) at a concentration of $50 \mu \mathrm{mol} \mathrm{L}^{-1}$ and $1000 \mu \mathrm{mol}$ $\mathrm{L}^{-1}$. Cultivation was carried out for the next 7 days. Each variant of the cultivation was performed in three replicates. After cultivation, the plants were harvested, the roots were washed with deionized water and the plants were divided into roots and leave and lyophilized. The dried roots and leaves were stored at $-24^{\circ} \mathrm{C}$ until analysis.

Table 1 Operational parameters for HPLC and ICP-MS

\begin{tabular}{ll}
\hline Settings & \\
\hline ICP-MS & Agilent 7500a \\
RF power & $1280 \mathrm{~W}$ \\
$\begin{array}{l}\text { Plasma, auxiliary and } \\
\text { nebulizer gas flow }\end{array}$ & $15.0,1.0$ and $1.05 \mathrm{~L} \mathrm{~min}{ }^{-1}$ \\
Cones & Sampler-Pt, Skimmer-Pt \\
Monitored isotopes & ${ }^{63} \mathrm{Cu},{ }^{65} \mathrm{Cu},{ }^{66} \mathrm{Zn},{ }^{68} \mathrm{Zn},{ }^{55} \mathrm{Mn},{ }^{95} \mathrm{Mo}$ \\
Dwell time & $0.1 \mathrm{~ms}$ \\
HPLC separation & \\
Pump & Agilent 1100 \\
Column & Superdex $200(10 \times 300 \mathrm{~mm} \times 10 \mu \mathrm{m})-$ \\
& GE Healthcare Life Sciences \\
Mobile phase & $10 \mathrm{mM}$ ammonium acetate buffer $(\mathrm{pH} 7.4)$ \\
Elution program & Isocratic \\
Flow & $0.5 \mathrm{~mL}$ min ${ }^{-1}$ \\
Injection volume & $100 \mu \mathrm{L}$ \\
Column temperature & $24{ }^{\circ} \mathrm{C}$ \\
\hline
\end{tabular}




\section{Sample mineralization}

After the end of cultivation, the dried plants were ground manually using an agate mortar and pestle, until a homogeneous powder was formed. For the determination of the total amount of elements in barley, a plant tissues $(0.05 \mathrm{~g}$ dry mass) were digested by microwave-assisted mineralization with a mixture of $5 \mathrm{~mL}$ of $\mathrm{HNO}_{3}$ and $3 \mathrm{~mL}$ of $\mathrm{H}_{2} \mathrm{O}_{2}$. After cooling down the digests were diluted with MQ water to the volume of $25 \mathrm{~mL}$ and then diluted before ICP MS analysis. Analyses were performed in triplicate. Samples and standard solutions were prepared with the addition of ${ }^{89} \mathrm{Y}$ as the internal standard. The external calibration curves were linear in the investigated range from 2 to $150 \mu \mathrm{g} \mathrm{L}^{-1}$ with $r^{2}$ above 0.998 .

\section{Synthesis of zinc/copper complexes with rutin and glycine}

Two different metal salts $\left(\left(\mathrm{CH}_{3} \mathrm{COO}\right)_{2} \mathrm{Zn}\right.$ and $\left.\mathrm{CuSO}_{4}\right)$ were dissolved with methanol. The salt concentration was $10 \mathrm{mg} \mathrm{mL}^{-1}$. Standard rutin was also dissolved in methanol with a final concentration of $15 \mathrm{mg} \mathrm{mL}^{-1}$. Methanol solution of rutin was mixed with a methanol solution of copper and zinc salts. All mixed solutions were incubated at $40{ }^{\circ} \mathrm{C}$ for $24 \mathrm{~h}$. To confirm that the compounds formed were certainly complexed the analysis was performed on a UV-VIS spectrophotometer. For example, the obtained spectrum of rutinzinc(II) complex solution was compared to the spectrum of rutin. In comparison to the spectrum of the rutin itself, the spectrum of rutin-zinc(II) shows the shift of absorption bands towards longer wavelengths, i.e. the bathochromic shift, which indicates that the relationship was made and is permanent.

Two different metal salts $\left(\mathrm{ZnSO}_{4}\right.$ and $\left.\mathrm{CuSO}_{4}\right)$ were dissolved with water. Standard glycine was also dissolved in water. The water solution of glycine was mixed with the water solution of copper and zinc salts, respectively, according to the 2:1 mole ratio. To confirm that the compounds formed were certainly complexed the analysis was performed on a UV-VIS spectrophotometer.

\section{In vitro simulation of gastrointestinal digestion}

The in vitro digestion method was based on Luten et al. modified to the studied barley grass [18]. $2.5 \mathrm{~mL}$ of gastric juice $(6 \% \mathrm{w} / \mathrm{v}$ pepsin in $0.15 \mathrm{M} \mathrm{NaCl}$, acidified to $\mathrm{pH} 1.8$ through $\mathrm{HCl}$ ) was added to $0.07 \mathrm{~g}$ of plant tissues and then shaken and sonicated for $10 \mathrm{~min}$ in an ultrasonic bath. In the next step, the mixture was incubated in the thermostatic water bath for $3.5 \mathrm{~h}$ at $37^{\circ} \mathrm{C}$. After incubation, the mixture was centrifuged at $4{ }^{\circ} \mathrm{C}$ for $20 \mathrm{~min}$ at $15,000 \mathrm{rpm}$. The supernatants were filtered through $0.45 \mu \mathrm{m}$ syringe filters
(Sigma-Aldrich, Bellefonte, PA, USA) and analyzed. For intestinal digestion, the $\mathrm{NaHCO}_{3}$ solution was added to the remaining part of the sample to obtain a neutral $\mathrm{pH}$. After that $2.5 \mathrm{~mL}$ of intestinal juice $(1.5 \% \mathrm{w} / \mathrm{v}$ pancreatin in $0.15 \mathrm{M} \mathrm{NaCl}$ ) was added and the mixture was incubated for $2 \mathrm{~h}$ at $37^{\circ} \mathrm{C}$. Following centrifugation and filtration of supernatant, the gastrointestinal extract was analyzed by SEC-ICP-MS.

To collect the information about the bioaccessibility of important nutrients from plant tissues by the human organism, the efficiency of enzymatic extraction was estimated by establishing the amounts of elements in digestion extracts against the total content of elements in mineralized samples.

\section{Results and discussion}

\section{Evaluation of total content of zinc and copper in plant tissues from enriched growing solutions}

The total concentration of selected elements was determined after microwave-assisted digestion of barley grass through ICP-MS. The results were obtained from three independent experiments. As the interest of this study, the following total amounts of zinc were identified and presented in Table 2.

The concentrations of the elements in the tissues of plants collected from the enriched growing solutions were high. The concentrations of the elements in plant tissues were significantly affected by the plant organ (leaves vs roots) and the growing solutions. The elements accumulated predominantly in roots.

It can be concluded that the content of zinc in roots growing on enriched in zinc solutions compared to the control increased. In the case of solutions with a concentration of $50 \mu \mathrm{mol} \mathrm{L}^{-1}$, this increase is most noticeable when the medium contained glycine-zinc(II). However, for solutions with a concentration of $1000 \mu \mathrm{mol} \mathrm{L}{ }^{-1}$, the increase is visible for all three solutions. For other elements, there was no relationship between their concentration and zinc concentration, but their concentration values varied for different seedlings.

A similar relationship was observed in leaves between the concentration of zinc in the control and barley grass cultured on the enriched media. The highest concentration of zinc was observed in the case of plant tissues cultured on a solution enriched in $1000 \mu \mathrm{mol} \mathrm{L}{ }^{-1}$ glycine-zinc(II) resented investigations shows that the content of zinc in the roots is much higher than in the leaves. Because the roots are responsible for collecting nutrients and transferring them to the leaves, we could found about $92 \%$ of zinc in the roots. It is important to mention that the presence of a higher amount of zinc in the growth solutions does not influence the concentration of copper in the plant (Fig. 1). 
Table 2 Total concentrations of manganese, copper, zinc and molybdenum in plant tissues growing on solutions enriched in various zinc/copper solutions

\begin{tabular}{|c|c|c|c|c|c|c|c|c|c|c|c|c|c|c|}
\hline \multicolumn{2}{|c|}{$\begin{array}{l}\text { Conc., } \mu \mathrm{mol} \\
\mathrm{L}^{-1}\end{array}$} & \multirow[t]{2}{*}{ RSD, $\%$} & 50 & $\mathrm{RSD}, \%$ & 1000 & $\mathrm{RSD}, \%$ & 50 & RSD, \% & 1000 & RSD, $\%$ & 50 & RSD, $\%$ & 1000 & RSD, $\%$ \\
\hline Contro & & & \multicolumn{4}{|c|}{ Zn(II)-Gly } & \multicolumn{4}{|c|}{$\mathrm{Zn}$ (II)-Rut } & \multicolumn{4}{|l|}{$\mathrm{ZnSO}_{4}$} \\
\hline \multicolumn{15}{|l|}{ Leaves } \\
\hline $\mathrm{Zn}$ & 55.060 & 2.60 & 89.490 & 2.09 & 158.600 & 1.95 & 61.280 & 1.72 & \multicolumn{2}{|c|}{104.6002 .47} & 60.250 & 0.08 & 131.94 & 0.12 \\
\hline $\mathrm{Cu}$ & 7.962 & 0.26 & 9.730 & 0.53 & 9.350 & 0.15 & 7.620 & 0.25 & \multicolumn{2}{|c|}{7.1400 .44} & 6.720 & 0.58 & \multicolumn{2}{|c|}{9.5100 .21} \\
\hline Mn & 21.212 & 0.04 & 28.530 & 0.78 & 23.340 & 1.10 & 18.560 & 1.53 & \multicolumn{2}{|c|}{20.8400 .98} & 19.820 & 0.35 & \multicolumn{2}{|c|}{25.3800 .22} \\
\hline Mo & 0.850 & 0.01 & 0.900 & 0.01 & 0.650 & 0.02 & 0.770 & 0.04 & \multicolumn{2}{|c|}{0.7100 .03} & 0.670 & 0.04 & \multicolumn{2}{|c|}{0.7400 .01} \\
\hline \multicolumn{15}{|l|}{ Roots } \\
\hline $\mathrm{Zn}$ & 605.330 & 2.13 & 791.040 & 2.95 & 2024.50 & 2.21 & 635.750 & 1.85 & 1646.91 & 2.63 & 660.320 & 3.23 & 1749.99 & 2.37 \\
\hline $\mathrm{Cu}$ & 16.900 & 1.25 & 7.260 & 0.58 & 3.820 & 2.97 & 10.470 & 0.67 & \multicolumn{2}{|c|}{7.7200 .86} & 6.980 & 0.12 & \multicolumn{2}{|c|}{8.7400 .08} \\
\hline Mn & 8.180 & 0.43 & 5.170 & 1.55 & 2.670 & 1.89 & 6.500 & 1.02 & \multicolumn{2}{|c|}{6.1701 .01} & 5.970 & 0.98 & \multicolumn{2}{|c|}{2.0900 .35} \\
\hline Mo & 0.850 & 0.06 & 1.240 & 0.12 & 3.820 & 1.11 & 1.130 & 0.05 & \multicolumn{2}{|c|}{1.4300 .13} & 1.050 & 0.03 & \multicolumn{2}{|c|}{2.1000 .15} \\
\hline \multicolumn{2}{|c|}{$\begin{array}{l}\text { Conc., } \mu \mathrm{mol} \\
\mathrm{L}^{-1}\end{array}$} & RSD, $\%$ & 50 & RSD, $\%$ & 1000 & $\mathrm{RSD}, \%$ & 50 & RSD, \% & 1000 & RSD, $\%$ & 50 & RSD, $\%$ & 1000 & RSD, $\%$ \\
\hline Contro & & & \multicolumn{4}{|c|}{$\mathrm{Cu}(\mathrm{II})$-Gly } & \multicolumn{4}{|c|}{$\mathrm{Cu}$ (II)-Rut } & \multicolumn{4}{|l|}{$\mathrm{CuSO}_{4}$} \\
\hline \multicolumn{15}{|l|}{ Leaves } \\
\hline $\mathrm{Cu}$ & 10.782 & 0.57 & 15.956 & 0.74 & 19.709 & 0.71 & 11.789 & 0.37 & 13.525 & 0.73 & 14.732 & 0.79 & 20.437 & 0.77 \\
\hline $\mathrm{Zn}$ & 86.900 & 3.31 & 99.842 & 2.79 & 91.079 & 2.14 & 99.920 & 5.66 & 101.415 & 3.31 & 86.725 & 1.90 & 80.231 & 4.87 \\
\hline $\mathrm{Mn}$ & 24.431 & 0.67 & 25.807 & 0.33 & 22.103 & 0.33 & 25.715 & 0.71 & 23.942 & 1.32 & 27.139 & 0.43 & 25.220 & 0.84 \\
\hline Mo & 0.943 & 0.03 & 0.897 & 0.04 & 0.652 & 0.03 & 0.994 & 0.00 & 0.898 & 0.06 & 0.748 & 0.02 & 0.609 & 0.02 \\
\hline \multicolumn{15}{|l|}{ Roots } \\
\hline $\mathrm{Cu}$ & 7.592 & 0.35 & 7.924 & 0.21 & 73.431 & 2.94 & 14.032 & 0.58 & 13.383 & 3.63 & 59.128 & 2.38 & 69.458 & 4.99 \\
\hline $\mathrm{Zn}$ & 607.837 & 4.05 & 480.369 & 5.02 & 616.310 & 4.27 & 605.349 & 3.06 & 612.330 & 2.94 & 510.497 & 4.92 & 466.813 & 1.46 \\
\hline $\mathrm{Mn}$ & 10.320 & 0.43 & 7.026 & 0.18 & 5.583 & 0.18 & 7.764 & 0.48 & 4.751 & 0.19 & 6.873 & 0.33 & 5.831 & 0.16 \\
\hline Mo & 0.294 & 0.02 & 0.328 & 0.00 & 0.290 & 0.01 & 0.278 & 0.01 & 0.313 & 0.01 & 0.275 & 0.01 & 0.322 & 0.03 \\
\hline
\end{tabular}

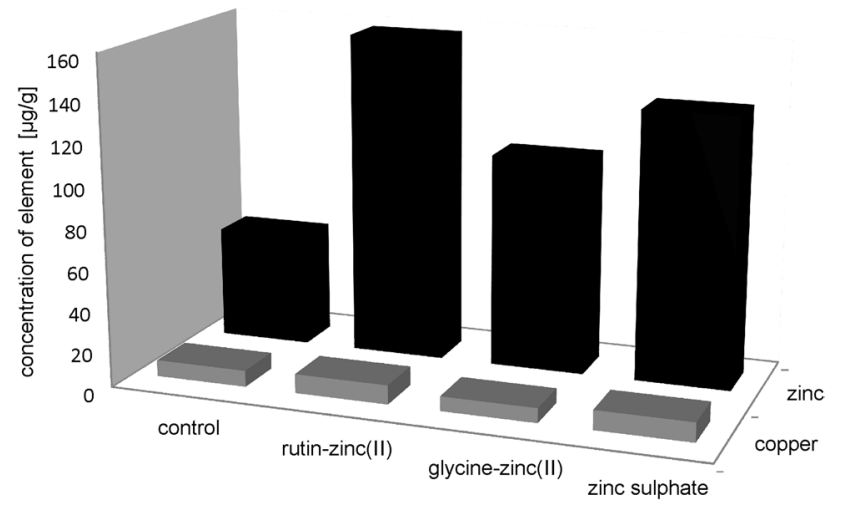

Fig. 1 The content of zinc and copper in leaves of barley grass

The content of copper in the roots growing on enriched in copper solutions compared to the control it contains only copper ions (not glycine-copper(II), applies to roots). In the case of solutions with a concentration of $50 \mu \mathrm{mol} \mathrm{L}{ }^{-1}$, this increase is most noticeable when the medium contained glycine-copper(II) and the copper ions.
Similarly, for solutions with a concentration of $1000 \mu \mathrm{mol}$ $\mathrm{L}^{-1}$, the increase is also observable for glycine-copper(II) and their salt. For other elements, there was no relationship between their concentration and copper concentration, but their concentration values also varied for different seedlings.

Presented investigations show that the content of copper in the roots is much higher than in the leaves. The highest concentration of copper was observed in the case of leaves cultured on a solution enriched in $1000 \mu \mathrm{mol} \mathrm{L}^{-1}$ copper glycine and copper-sulphate solutions (Fig. 2).

\section{Evaluation of bioaccessibility of zinc and copper from the barley grass by the human organism}

The efficiency of extraction of copper and zinc after enzymatic extraction is presented in Table 3 . The $\%$ of bioaccessibility of the copper/zinc in plant tissues was calculated based on copper or zinc concentration in gastric and gastrointestinal extracts, through the following formula: 


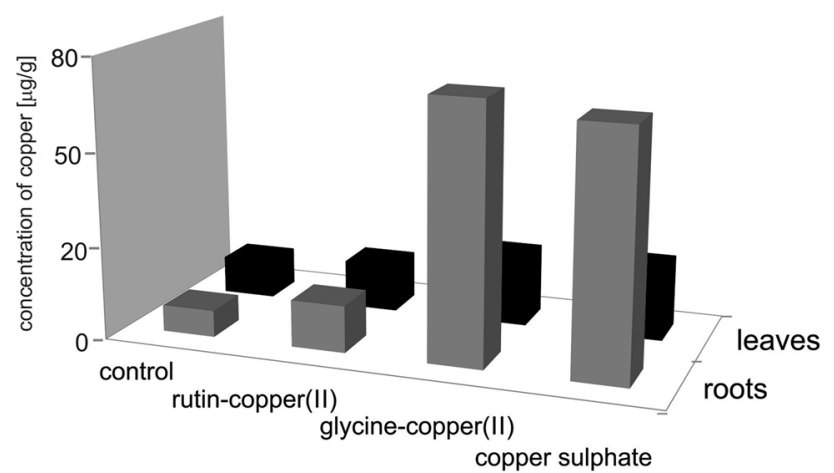

Fig. 2 The content of copper in barley grass leaves (black) and roots (grey)

$\%$ Bio accessibility $=\frac{[\mathrm{GC}] \mathrm{or}[\mathrm{GIC}]}{[\mathrm{TC}]} \times 100 \%$,

where $[\mathrm{GC}]=$ content of copper or zinc in the gastric digest, $[\mathrm{GIC}]=$ content of copper or zinc in gastrointestinal digest and $[\mathrm{TC}]=$ total concentration of copper or zinc in barley grass sample.

Zinc: The presented results show that after the simulation of gastric digestion, the bioaccessibility of zinc in leaves growing on enriched solutions in glycine-zinc(II) and zinc-sulphate is higher than $60 \%$ of total zinc content. The obtained results could indicate that high molecular compounds (HMW) are the main ligands binding zinc in plant tissues. When the concentration of metal in the growing solution was higher (enriched in $1000 \mu \mathrm{mol} \mathrm{L}^{-1}$ of $\mathrm{Zn}$ ), the lower content of zinc was extracted from plant tissues. However, after the end of digestion simulation, the bioaccessibility of zinc was about $50 \%$ from plant tissues growing on solutions enriched in rutin-zinc(II) what leads to the conclusion that zinc complexed by rutin it is the form which is the most bioaccessible for the human body.

Copper: The presented results show that after the simulation of gastric digestion, the bioaccessibility of copper from leaves is $50 \%$ of total copper content. However, when the

Table 3 Bioaccessibility of copper and zinc in plant tissues growing on solutions enriched in various zinc/copper solutions

\begin{tabular}{|c|c|c|c|c|c|c|c|}
\hline & Conc. $\mu \mathrm{mol} \mathrm{L}{ }^{-1}$ & 50 & 1000 & 50 & 1000 & 50 & 1000 \\
\hline $\mathrm{Zn}$ & Control & Zn(II)-Gly & & Zn(II)-Rut & & $\mathrm{ZnSO}_{4}$ & \\
\hline \multicolumn{8}{|l|}{ Leaves } \\
\hline & 55.060 & 89.490 & 158.600 & 61.280 & 104.600 & 60.250 & 131.94 \\
\hline Pepsin* & 28.09 & 77.08 & 26.45 & 24.85 & 30.38 & 37.96 & 61.06 \\
\hline Bioaccessibility, $\%$ & 51.01 & 86.13 & 16.68 & 40.47 & 29.04 & 63.00 & 46.28 \\
\hline Pancreatin* & 25.89 & 33.95 & 38.98 & 25.52 & 59.28 & 28.87 & 38.91 \\
\hline Bioaccessibility, \% & 47.02 & 37.94 & 24.58 & 41.64 & 56.67 & 47.91 & 29.49 \\
\hline \multicolumn{8}{|l|}{ Roots } \\
\hline & 605.330 & 791.040 & 2024.50 & 635.750 & 1646.91 & 660.320 & 1749.99 \\
\hline Pepsin* & 121.38 & 62.54 & 618.19 & 122.75 & 1035.14 & 194.76 & 459.96 \\
\hline Bioaccessibility, \% & 20.05 & 7.91 & 30.54 & 19.31 & 62.58 & 29.49 & 26.28 \\
\hline Pancreatin* & 228.14 & 111.51 & 427.73 & 228.97 & 135.48 & 177.94 & 79.77 \\
\hline Bioaccessibility, \% & 37.69 & 14.10 & 21.13 & 36.02 & 8.23 & 26.95 & 4.56 \\
\hline $\mathrm{Cu}$ & Control & $\mathrm{Cu}(\mathrm{II})$-Gly & & $\mathrm{Cu}(\mathrm{II})-\mathrm{Rut}$ & & $\mathrm{CuSO}_{4}$ & \\
\hline \multicolumn{8}{|l|}{ Leaves } \\
\hline & 10.782 & 15.956 & 19.709 & 11.789 & 13.525 & 14.732 & 20.437 \\
\hline Pepsin* & 8.03 & 7.95 & 3.44 & 7.55 & 0.51 & 9.23 & 5.79 \\
\hline Bioaccessibility, \% & 74.49 & 49.81 & 17.46 & 64.04 & 3.77 & 62.65 & 28.33 \\
\hline Pancreatin* & 4.38 & 6.28 & 8.52 & 5.15 & 6.30 & 7.08 & 9.02 \\
\hline Bioaccessibility, \% & 40.63 & 39.34 & 43.25 & 43.68 & 46.60 & 48.06 & 44.13 \\
\hline \multicolumn{8}{|l|}{ Roots } \\
\hline & 8.182 & 7.269 & 73.431 & 10.472 & 13.383 & 59.128 & 69.458 \\
\hline Pepsin* & 3.50 & 13.19 & 10.00 & 5.46 & 2.88 & 26.08 & 9.73 \\
\hline Bioaccessibility, \% & 42.79 & 18.17 & 13.61 & 52.15 & 21.52 & 44.11 & 14.01 \\
\hline Pancreatin* & 5.25 & 1.97 & 12.11 & 7.46 & 2.26 & 23.72 & 8.75 \\
\hline Bioaccessibility, \% & 64.18 & 27.15 & 16.49 & 71.25 & 16.88 & 40.12 & 12.60 \\
\hline
\end{tabular}

The extraction efficiency is presented as a bioaccessibility

*The concentration of selected metals $\left[\mu \mathrm{mol} \mathrm{L} \mathrm{L}^{-1}\right]$ in extracts after the enzymatic digestion 
concentration of metal in a growing solution is enriched in a much higher concentration of eluent $\left(1000 \mu \mathrm{mol} \mathrm{L}^{-1}\right.$ of $\mathrm{Cu}$ ), only $15-30 \%$ of copper was extracted. The results were similar to those obtained for the zinc solution. It follows, that the presence of higher concentrations of elements in the plant tissues may affect their lower bioavailability for humans organisms.

After the end of the simulation of digestion, bioaccessibility of copper was about $40 \%$ which leads to the conclusion that copper compounds present in leaves are bioaccessible for the human body.

\section{SEC-ICP-MS profiling of gastric and gastrointestinal extracts}

Coupling the size exclusion chromatography with inductively coupled plasma mass spectrometry (SEC-ICP-MS) allows the element-specific detection of eluted compounds. The eluate from the column was fed directly into the ICP-MS. The extracts of plant tissues after the simulation of gastric and gastrointestinal digestion were examined.

The chromatograms obtained for leaves gastric and gastrointestinal extracts growing on control solutions consisted of four peaks at a similar time of retentions (Fig. 3). We could observe additional peaks at $\operatorname{tr}=27 \mathrm{~min}$ and $\operatorname{tr}=30 \mathrm{~min}$ for plant tissues gastric extracts growing on solutions enriched in zinc, which cannot be observed in control extracts. Both signals ( $a t \operatorname{tr}=27 \mathrm{~min}$ and $\operatorname{tr}=30 \mathrm{~min}$ ) probably correspond to digestion products of zinc compounds that are created in plant tissues due to cultivation. Furthermore, we could observe one additional peak at $\operatorname{tr}=28 \mathrm{~min}$, after the gastrointestinal digestion.

In a case of copper, the chromatograms obtained for leaves gastric and gastrointestinal extracts, growing on solutions enriched in copper, consisted of five peaks (Fig. 3). Furthermore, we could observe an additional peak only after the gastrointestinal digestion, at $\operatorname{tr}=22 \mathrm{~min}$ for plant tissues growing on solutions enriched in copper sulphate and glycine-copper(II). The signal corresponds probably to digestion products of copper which are created in plant tissues due to cultivation.

The presented results indicate the ability of ligands interaction with copper and zinc in plant tissues and improving the bioaccessibility of copper by the human organism.

\section{Conclusions}

In the present study, ICP-MS and SEC-ICP-MS techniques were used for the determination of zinc and copper content in plant tissues growing on solutions enriched in various zinc/copper forms (sulphate, glycine complex, rutin complex). This study proved that barley grass overgrowing on enriched solutions accumulate much higher amounts of $\mathrm{Cu}$ and $\mathrm{Zn}$ than the plants from control sites. The highest contents of metals were found in the roots, but their levels in the leaves were elevated as well, implying a possibility of transport of zinc/copper species along the food chain. The highest accumulation of zinc and copper we can observe in plant tissues cultivated on solutions enriched in the glycinezinc(II), glycine-copper(II) and sulphate-copper(II).
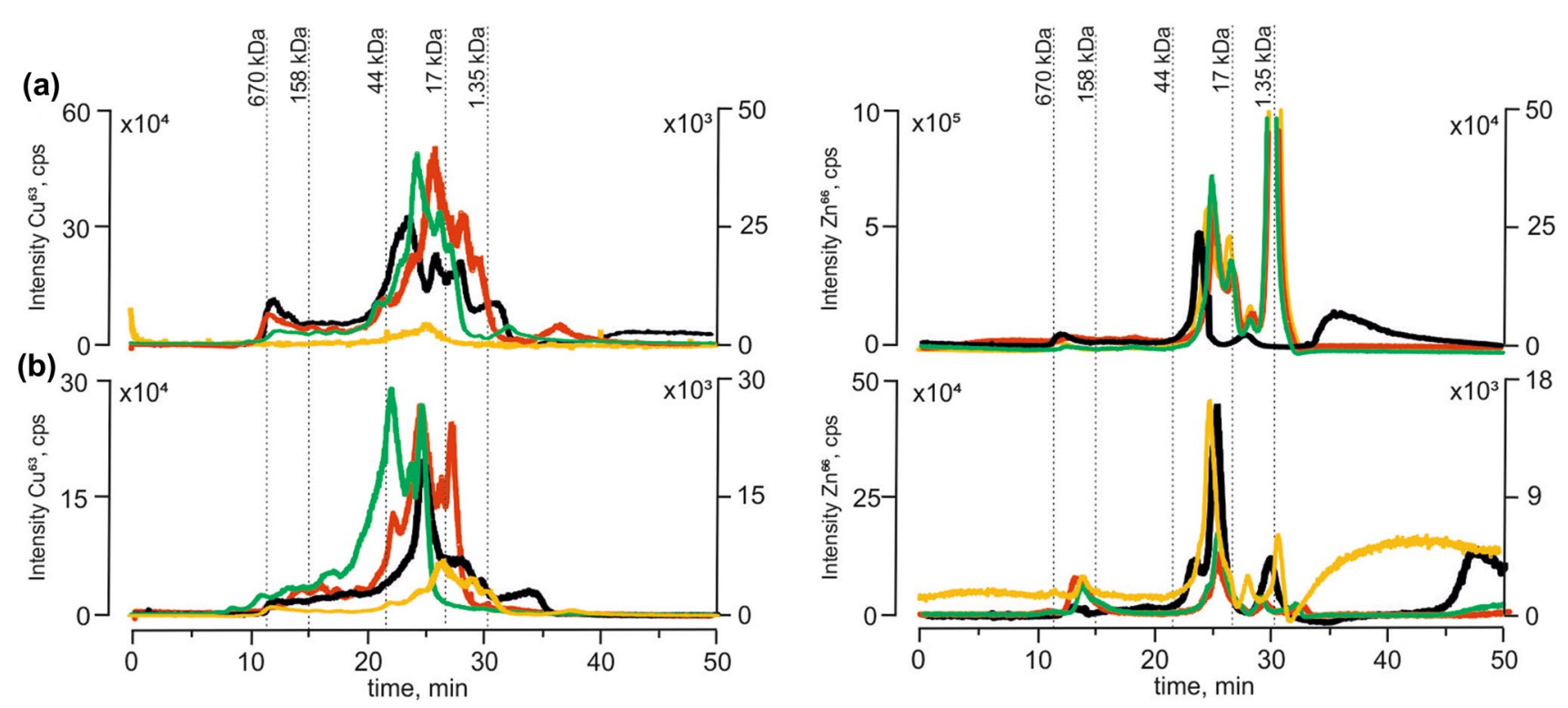

Fig. 3 SEC-ICP-MS chromatograms for copper and zinc obtained for leaves extracts after the in vitro simulation of a gastric digestion and $\mathbf{b}$ gastrointestinal digestion (line: black—control; red—glycine; green—sulphate, yellow—rutin growing solution) 
After the end of digestion simulation, zinc bioaccessibility was about $50 \%$ from plant tissues growing on solutions enriched in the rutin-zinc(II) and zinc sulphate. Likewise, the higher bioaccessibility of copper (40\%) from plant tissues growing on solutions enriched in rutin-copper(II), glycine-copper(II) and copper sulphate. The SEC-ICP-MS result indicates the ability of ligands interaction with copper and zinc in barley grass tissues and improving the bioaccessibility of copper by the human organism.

Funding The authors are thankful for the National Science Centre, Poland (Grant Number 2017/01/X/ST4/01331) and Warsaw University of Technology for financial support of the presented study.

\section{Compliance with ethical standards}

Conflict of interest The authors declare that they have no conflict of interest.

Open Access This article is licensed under a Creative Commons Attribution 4.0 International License, which permits use, sharing, adaptation, distribution and reproduction in any medium or format, as long as you give appropriate credit to the original author(s) and the source, provide a link to the Creative Commons licence, and indicate if changes were made. The images or other third party material in this article are included in the article's Creative Commons licence, unless indicated otherwise in a credit line to the material. If material is not included in the article's Creative Commons licence and your intended use is not permitted by statutory regulation or exceeds the permitted use, you will need to obtain permission directly from the copyright holder. To view a copy of this licence, visit http://creativecommons.org/licenses/by/4.0/.

\section{References}

1. Ruzik L, Kwiatkowski P (2018) Application of CE-ICP-MS and CE-ESI-MS/MS for identification of Zn-binding ligands in Goji berries extracts. Talanta 183:102-107. https://doi.org/10.1016/j. talanta.2018.02.040

2. Wojcieszek J, Kwiatkowski P, Ruzik L (2017) Speciation analysis and bioaccessibility evaluation of trace elements in goji berries (LyciumBarbarum L.). J Chromatogr A. https://doi.org/10.1016/j. chroma.2017.02.069

3. Slaveykova VI, Wilkinson KJ (2005) Predicting the bioavailability of metals and metal complexes: critical review of the biotic ligand model. Environ Chem 2:9-24. https://doi.org/10.1071/en04076

4. Husted S, Mikkelsen BF, Jensen J, Nielsen NE (2004) Elemental fingerprint analysis of barley (Hordeumvulgare) using inductively coupled plasma mass spectrometry, isotope-ratio mass spectrometry, and multivariate statistics. Anal Bioanal Chem 378:171-182. https://doi.org/10.1007/s00216-003-2219-0

5. Bettenhausen HM, Barr L, Broeckling CD et al (2018) Influence of malt source on beer chemistry, flavor, and flavor stability. Food Res Int 113:487-504. https://doi.org/10.1016/j.foodr es.2018.07.024

6. Persson DP, Hansen TH, Laursen KH et al (2009) Simultaneous iron, zinc, sulfur, and phosphorus speciation analysis of barley grain tissues using SEC-ICP-MS and IP-ICP-MS. Metallomics 1:418-426. https://doi.org/10.1039/b905688b

7. Bonoli M, Verardo V, Marconi E, Caboni MF (2004) Antioxidant phenols in barley (Hordeumvulgare L.) flour: comparative spectrophotometric study among extraction methods of free and bound phenolic compounds. J Agric Food Chem 52:5195-5200. https:// doi.org/10.1021/jf040075c

8. Hernanz D, Nuñez V, Sancho AI et al (2001) Hydroxycinnamic acids and ferulic acid dehydrodimers in barley and processed barley. J Agric Food Chem 49:4884-4888. https://doi.org/10.1021/ jf010530u

9. Goupy P, Hugues M, Boivin P, Amiot MJ (1999) Antioxidant composition and activity of barley (Hordeumvulgare) and malt extracts and of isolated phenolic compounds. J Sci Food Agric 79:1625-1634. https://doi.org/10.1002/(SICI)1097-0010(19990 9)79:12\%3c1625:AID-JSFA411\%3e3.0.CO;2-8

10. Park MJ, Seo WD, Kang Y-H (2015) The antioxidant properties of four Korean barley cultivars at different harvest times and profiling of major metabolites. J Agric Sci. https://doi.org/10.5539/jas. v7n10p94

11. Ikeguchi M, Tsubata M, Takano A et al (2014) Effects of young barley leaf powder on gastrointestinal functions in rats and its efficacy-related physicochemical properties. Evid Based Complement Altern Med 2014:974840. https://doi.org/10.1155/2014/974840

12. Lahouar L, El-Bok S, Achour L (2015) Therapeutic potential of young green barley leaves in prevention and treatment of chronic diseases: an overview. Am J Chin Med 43:1311-1329. https://doi. org/10.1142/S0192415X15500743

13. Zeng Y, Pu X, Yang J et al (2018) Preventive and therapeutic role of functional ingredients of barley grass for chronic diseases in human beings. Oxid Med Cell Longev 2018:1-15. https://doi. org/10.1155/2018/3232080

14. Carbonell-Capella JM, Buniowska M, Barba FJ et al (2014) Analytical methods for determining bioavailability and bioaccessibility of bioactive compounds from fruits and vegetables: a review. Compr Rev Food Sci Food Saf 13:155-171. https://doi. org/10.1111/1541-4337.12049

15. Zhu K-X, Wang X-P, Guo X-N (2015) Isolation and characterization of zinc-chelating peptides from wheat germ protein hydrolysates. J Funct Foods 12:23-32. https://doi.org/10.1016/J. JFF.2014.10.030

16. Ovca A, Van Elteren JT, Falnoga I, Šelih VS (2011) Speciation of zinc in pumpkin seeds (Cucurbitapepo) and degradation of its species in the human digestive tract. Food Chem 128:839-846. https://doi.org/10.1016/j.foodchem.2011.03.102

17. Stelmach E, Pohl P, Szymczycha-Madeja A (2014) Evaluation of the bioaccessibility of $\mathrm{Ca}, \mathrm{Fe}, \mathrm{Mg}$ and $\mathrm{Mn}$ in ground coffee infusions by in vitro gastrointestinal digestion. J Braz Chem Soc 25:1993-1999. https://doi.org/10.5935/0103-5053.20140183

18. Wojcieszek J, Ruzik L (2016) Operationally defined species characterization and bioaccessibility evaluation of cobalt, copper, and selenium in cape gooseberry (PhysalisPeruviana L.) by SEC-ICP MS. J Trace Elem Med Biol 34:15-21. https://doi.org/10.1016/j. jtemb.2015.12.001

Publisher's Note Springer Nature remains neutral with regard to jurisdictional claims in published maps and institutional affiliations. 